Research Article

\title{
Total Testosterone Level is Lower in Women Consuming Combined Oral Contraception with Impaired Sexual Function
}

\section{Kadar Testosteron Total lebih Rendah pada Perempuan yang Mengonsumsi Pil KB Kombinasi dengan Fungsi Seksual Terganggu}

\author{
Yuniarty Amra, Josephine L Tumedia, Eddy Hartono \\ Department of Obstetrics and Gynecology \\ Faculty of Medicine University of Hasanuddin/ \\ Dr. Wahidin Sudirohusodo Hospital \\ Makassar
}

\begin{abstract}
Objectives: The aim of this research was to assess the relationship between total testosterone level and female sexual function based on Female Sexual Function Index (FSFI) among the acceptors of combined oral contraceptive pill.

Methods: The research was conducted in BLU of Dr. Wahidin Sudirohusodo Hospital and several teaching hospitals in obstetrics and gynecology sections of Medical faculty, Hasanuddin University from October to December 2012. This study assessed sexual function among 60 women as the acceptors of combined oral contraceptive pill. Sexual function was assessed using FSFI questionnaire which had been validated in several countries. This research used cross sectional design and the sample was selected using consecutive sampling method. The data were processed using SPSS with independent $t$ test of the significant level of 0.05 .

Results: The results of the research reveal that total testosterone level among the acceptors of combined oral contraceptive pill who have impaired sexual function is low. The result of the correlation test between testosterone level and FSFI score indicates a significant level $(p<0.05)$ with a correlation coefficient of $(r)=0.737$. The testosterone level of female who have impaired sexual function is significantly different $(p<0.05)$ from women who have normal sexual function. The cut off testosterone level that could indicate the occurrence of sexual dysfunction is $12.4 \mathrm{ng} / \mathrm{dl}$.
\end{abstract}

Conclusion: The total testosterone level among the acceptors of combined oral contraceptive pill who have impaired sexual function is lower than others who have no impaired sexual function.

[Indones J Obstet Gynecol 2013; 1-3: 129-33]

Keywords: combined oral contraceptive pill, FSFI, sexual function, total testosterone level

\begin{abstract}
Abstrak
Tujuan: Penelitian ini bertujuan menilai hubungan kadar testosteron total dengan fungsi seksual perempuan berdasarkan female sexual function index (FSFI) pada akseptor pil KB kombinasi.

Metode: Penelitian ini dilakukan di BLU Rumah Sakit Dr. Wahidin Sudirohusodo dan beberapa rumah sakit pendidikan bagian obstetrik dan ginekologi Fakultas Kedokteran Unhas selama Oktober sampai dengan Desember 2012. Sampel penelitian sebanyak 60 orang akseptor pil KB kombinasi. Pengambilan sampel dilakukan secara consecutive sampling. Penilaian fungsi seksual dilakukan dengan kuesioner FSFI yang telah divalidasi di beberapa negara dengan metode potong lintang (cross sectional). Pengolahan data menggunakan SPSS versi 16 melalui independent $t$-Test dengan tingkat signifikansi 0.05 .

Hasil: Hasil penelitian menunjukkan bahwa kadar testosteron total pada akseptor pil KB kombinasi yang fungsi seksualnya terganggu adalah rendah. Hasil uji korelasi antara kadar testosteron dengan skor FSFI menunjukkan korelasi bermakna $(p<0.05)$ dengan koefisien korelasi $(r)=0.737$. Kadar testosteron perempuan yang terganggu fungsi seksualnya berbeda secara bermakna $(p<0.05)$ dengan perempuan yang tidak terganggu fungsi seksualnya. Cut off kadar testosteron yang dapat menunjukkan terjadinya gangguan fungsi seksual, yaitu, $12,4 \mathrm{ng} / \mathrm{dl}$.
\end{abstract}

Kesimpulan: Kadar testosteron total pada akseptor pil KB kombinasi yang fungsi seksualnya terganggu adalah lebih rendah dban-dingkan dengan yang tidak terganggu fungsi seksualnya.

[Maj Obstet Ginekol Indones 2013; 1-3: 129-33]

Kata kunci: akseptor pil KB kombinasi, FSFI, fungsi seksual, kadar testosteron total

Correspondence: Yuniarti Amra. Jln. Syekh Yusuf V/9 Sungguminasa. Telephone: 081241202093.

Email: yuniarty_amra@yahoo.co.id

\section{INTRODUCTION}

Female sexual function is affected by various factors, including sex hormones (estrogen, androgen, and progesterone) that have different effects on vaginal tissue and the central nervous system. Oral Estrogen increases Sex Hormone Binding Globulin (SHBG). SHBG is a protein that transport sexual hormone in the liver, which can increase or de- crease, according to its androgen and anti-androgenic properties. Testosterone has a high affinity for SHBG, and high SHBG levels can reduce levels of free testosterone, which is important for sexual function. ${ }^{1}$

It is suggested that there is a relationship between the combined oral contraceptive pill and sexual dysfunction, although the effect of combined 
oral contraceptive pill is still unclear. Birth control pills contain a combination of estrogen ethinylestradiol (EE) and the synthetic progestin that can affect serum levels of SHBG and also can potentially affect the female sexual function. ${ }^{2-5}$

Graham et al in 2007 examined the serum levels of total testosterone, free testosterone, dehydroepiandrosterone sulfate among user of progestin combined oral contraceptive pill. Significant decrease has been shown in 3 months. ${ }^{6}$ They also found that there is a correlation between a low level of total testosterone, free testosterone levels and sexual desire. However, some women who have low testosterone levels show no impairment on sexual desires among them. Thus, the authors concluded that some women may be more sensitive to changes in testosterone levels. Serum levels of free testosterone after the use of 25 and $35 \mu \mathrm{g}$ $\mathrm{EE}$ and other progestin have been studied by Greco et al in 2007. Greco found that a low dose of EE associated with a smaller decline of free testosterone. Two recent research studying the effects of oral contraceptives on serum SHBG levels and the possible correlation with sexual function. ${ }^{7}$ Panzer et al examined 124 serum levels in women with sexual dysfunction who use and do not use combination oral contraceptives. ${ }^{8}$ SHBG levels increased four times higher among users, and FSFI scores (Female Sexual Function Index) was also lower. Warnock et al measured SHBG, total testosterone and free testosterone levels in 106 women with sexual dysfunction, 43 of them is the user of combined oral contraceptive pill. The levels of total SHBG and free testosterone levels were lower among non-users compared among user, but both suffered sexual function disorders. ${ }^{6-9}$

Female Sexual Function Index (FSFI) is a valid and accurate measurement of female sexual function. The questionnaire consisted of 19 questions divided into six sub score, including sexual desire, arousal, lubrication, orgasm, satisfaction, and pain. ${ }^{10}$ FSFI is used to measure sexual function including sexual desire in the last 4 weeks. High scores on each level domain showed better sexual function. ${ }^{11}$

Based on the formulation of the theory and some of the above studies, there is a strong need to conduct a study which assessed the relationship between total testosterone levels with sexual function among the user of combination oral contraceptive. Thus it can be used as consideration for the provision of counseling, information and education about relationships between pill combinations and female sexual function.

\section{METHODS}

\section{Location and Research Design}

The research was carried out in several teaching hospital in Obstetrics and Gynecology of Hasanuddin University Makassar as well as Dr. Wahidin Sudirohusodo hospital and its networks. The study was conducted from October 2012 to December 2012. Research design used in this study is crosssectional which aims to determine the effect of combined oral contraceptive pill in changing total testosterone levels and the sexual function of women.

\section{Population and Sample}

The population in this study is the combined oral contraceptive pill acceptors in Dr. Wahidin Sudirohusodo hospital in and its networks in department of Obstetrics and Gynecology in Makassar. Samples were new acceptors of combination tablets that have signed informed consent. They were taken in accordance with the inclusion and exclusion criteria. Minimum sample size in this study was calculated based on the formula test of correlation between the two variables which obtained as many as 60 people.

Inclusion criteria for this sample were primiparous, aged between 20-35 years, not pregnant or breast-feeding, new acceptors combined oral contraceptive pill and not using hormonal birth control method before, body mass index (BMI) normal 18.5 to $23 \mathrm{~kg} / \mathrm{m}^{2}$, have no a contraindication to hormonal contraception, do not suffer from chronic diseases, living with her husband, did not give birth with vacuum extraction/forceps, episiotomy is not performed at the time of birth, not taking medication or a supplement for weight loss drugs that alter lipid profiles such as anti-cholesterol drugs and anti diabetic drugs, no alcohol, no history of sexual trauma and filling Informed Consent. Exclusion criteria were subjects withdrew from the study or drops out during the study period or changes the way or method of family planning. 


\section{Processing and Presentation of Data}

Processing and analyzing the data is using a statistical program. Data analysis includes descriptive part which calculate the amount and determine the percentage, and analysis using statistical test of Pearson correlation test and independent t-test with significance level of $p<0.05$ has been done.

\section{RESULTS}

Sample is obtained as much as 60 people, aged 2033 years with a mean (SD) $=24.5$ (3.3) years. Duration of acceptor 6-20 months with a mean (SD) $=11.1$ (3.3) months. Testosterone levels vary widely, ranging from 2.4 to $61.3 \mathrm{ng} / \mathrm{ml}$ with a mean $(\mathrm{SD})=14.53$ (11.92) ng/dl; while FSFI scores varied between 12.2 to 33.1 with a mean (SD ) $=24.69$ (4.64), (Table 1)

Table 1. Variable Description

\begin{tabular}{|c|c|c|c|c|}
\hline \multirow{2}{*}{ Variable } & \multicolumn{3}{|c|}{ Descriptive statistics } & \multirow{2}{*}{$\begin{array}{c}\text { Data } \\
\text { Distribution }\end{array}$} \\
\hline & $\mathbf{n}$ & $\begin{array}{l}\text { Minimal/ } \\
\text { Maximum }\end{array}$ & Mean (SD) & \\
\hline Age (years) & 60 & $20 / 33$ & $25.4(3.3)$ & Normal \\
\hline $\begin{array}{l}\text { Duration of acceptor } \\
\text { (month) }\end{array}$ & 60 & $6 / 20$ & $11.1(3.3)$ & Abnormal \\
\hline $\begin{array}{l}\text { Testosteron's level } \\
\text { (ng/dl) }\end{array}$ & 60 & $2.4 / 61.3$ & $14.53(11.92)$ & Normal \\
\hline FSFI & 60 & $12,2 / 33.1$ & $24.69(4.6)$ & Normal \\
\hline
\end{tabular}

\section{Multivariate analysis}

Pearson correlation which used to test the FSFI and total testosterone levels showed significant corre- lation $(\mathrm{p}<0.05)$ with a correlation coefficient $(\mathrm{r})$ $=0.737$. Total testosterone, age and no longer be acceptors has a significant correlation ( $p>0,05)$. The lower total testosterone levels, the lower the value of FSFI (Table 2).

Table 2. The Correlation of Age, Duration of Acceptor, Testosteron's Level and FSFI

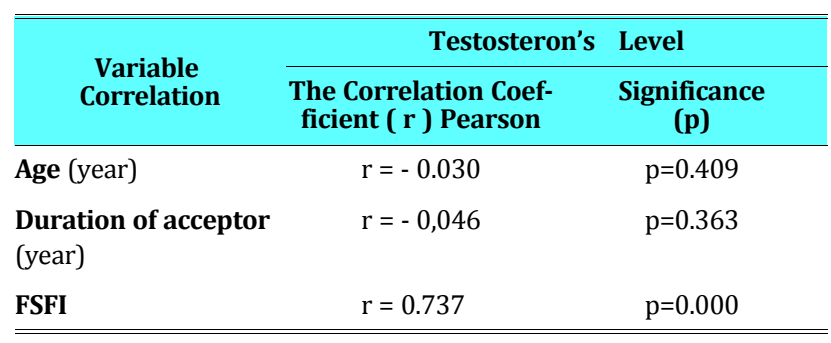

FSFI score $=26.55$ interpreted have disturbed sexual function, the analysis of independent $t$ test showed that total testosterone levels who have impaired sexual function was significantly different $(\mathrm{p}<0.05)$ with a group who has no sexual function. Testosterone levels in those with impaired smaller than the normal group. Age showed no significant difference in statistics ( $p$ > 0.05); (Table 3).

Table 3 showed the cut off testosterone levels which showed the occurrence of sexual dysfunction; namely: $12.4 \mathrm{ng} / \mathrm{dl}$. That is, if levels $<12.4$ $\mathrm{ng} / \mathrm{dl}$ can predict sexual interference. Based on the minimum value of the group who have no impaired sexual function (12.4 ng/dl), the levels $<12.4 \mathrm{ng} / \mathrm{dl}$ showed none of whom still have normal sexual function. Even, among people who have total testosterone levels from 12.4 to $14.74 \mathrm{ng} / \mathrm{dl}$, there are still individuals who experience sexual dysfunction. Total testosterone levels $>14.74 \mathrm{ng} / \mathrm{dl}$ usually do not experience sexual dysfunction.

Table 3. Differences in Age, Duration of Acceptor and Testosterone Levels between the Groups without Sexual Dysfunction.

\begin{tabular}{|c|c|c|c|c|c|}
\hline \multirow{3}{*}{ Variable } & \multicolumn{4}{|c|}{ Sexual Disfunction } & \multirow{3}{*}{$\underset{\text { t-test }}{\text { Independent }}$} \\
\hline & \multicolumn{2}{|c|}{ Yes $(n=31)$} & \multicolumn{2}{|c|}{ No $(n=29)$} & \\
\hline & Min/Max & Mean(SD) & Min/Max & Mean(SD) & \\
\hline Age (years) & $20 / 33$ & $25.1(3.0)$ & $20 / 32$ & $25.7(3.7)$ & $\mathrm{p}=0.497$ \\
\hline Duration of acceptor (month) & $6 / 17$ & $11.1(3.1)$ & $6 / 20$ & $11.1(3.5)$ & $\mathrm{p}=0.974$ \\
\hline Testosteron's level (ng/dl) & $2.4 / 14.74$ & $6.31(3.58)$ & $12.4 / 61.3$ & $23.31(11.44)$ & $\mathrm{p}=0.000$ \\
\hline
\end{tabular}




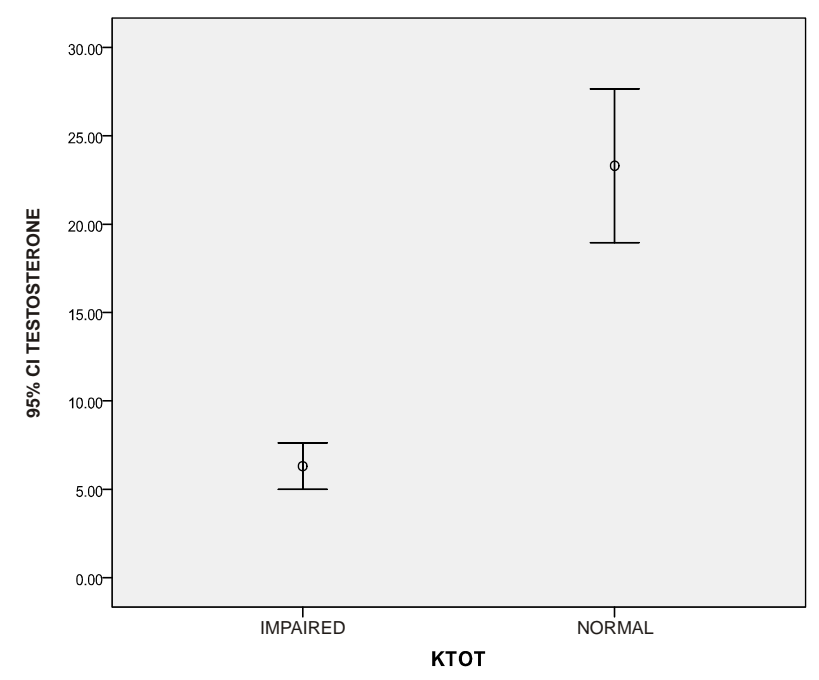

Figure 1. Differences in testosterone levels between groups of impaired sexual function and normal sex function.

Figure 1 shows the difference in testosterone levels between the groups with impaired sexual function and the group who has no impaired sexual function. Total testosterone levels (mean and 95\% CI) in those with impaired sexual function are lower than the group without sexual dysfunction.

\section{DISCUSSION}

This study showed that a total testosterone level in the combined oral contraceptive pill acceptors who has impaired sexual function is low. Sexual function is dynamic and it is influenced by changes throughout life transitions, such as first sexual intercourse, pregnancy, children, and partner. Age ultimately affects the sexual function of a women through processes such as menopause and health decline along with the increasing age 12 . Age is biased with duration of having relationship and number of children. With age, the quality of the relationship and the mount of children will be more.

Duration as an acceptor 6-20 months with a mean $(\mathrm{SD})=11.1$ (3.3) months. Testosterone levels are very varied, ranging from 2.4 to $61.3 \mathrm{ng} / \mathrm{ml}$ with a mean $(\mathrm{SD})=14.53(11.92) \mathrm{ng} / \mathrm{dl}$; while FSFI scores varied between 12.2 to 33.1 with a mean $(S D)=24.69(4,64)$. Graham et al examined the serum levels of total testosterone, free testosterone, dehydroepiandrosterone sulfate during the use of oral contraceptives that use same progestin. A significant reduction was obtained after 3 months.
They found also that there is a statistical correlation between low total testosterone and free testosterone levels as well as frequency of sexual desire. However, some women showed no loss of sexual function despite low testosterone levels.

Results of correlation between testosterone levels and FSFI showed significant correlation $(\mathrm{p}<$ $0.05)$ with a correlation coefficient $(r)=0.737$. The correlation of testosterone level with age and duration as an acceptor was shown to have no a significant correlation ( $p>0.05)$. The lower levels of testosterone, the lower the value FSFI. Warnock et al measured levels of total testosterone, SHBG, and free testosterone levels in 106 women with impaired sexual function, 43 of them are combined oral contraceptive pill acceptors. Among the combined oral contraceptive pill acceptors, higher levels of SHBG and total as well as free testosterone levels is lower than non-acceptors, but they experience sexual dysfunction.

FSFI score $=26.55$ declared as having impaired sexual function, the independent $t$ test analysis found that testosterone levels among women who has impaired sexual function and their counterparts was statistically significant $(p<0.05)$. Testosterone levels in those with impaired sexual function are smaller than their counterparts. The age showed no significant difference $(p>0.05)$. Serum levels of free testosterone with the use of 25 and $35 \mathrm{mcg}$ ethinylestradiol and same progestin has been investigated by Greco et al in 2007.7 They found that low doses of ethinylestradiol were associated with a lesser decline of free testosterone. Panzer et al examined 124 serum levels in women with decreased sexual function who did and did not use oral contraception. SHBG levels increased four times higher in the women using oral contraception, and FSFI scores were also lower. ${ }^{8}$

\section{CONCLUSIONS}

We conclude that total testosterone levels were lower among the combined oral contraceptive pill acceptors. The lower total testosterone levels, the lower FSFI scores. Cut off value of testosterone levels showed that the occurrence of sexual dysfunction; namely: $12.4 \mathrm{ng} / \mathrm{dl}$. As a suggestion, the further research is needed especially with more number of samples. There is a strong need to get knowledgeable health care provider who can pro- 
vide education and counseling on sexual function and sexual activity in particular about family planning the candidates of combined oral contraceptive pill acceptor.

\section{REFFERENCES}

1. Goldstein I, Traish A \& Munarriz R. The role of sex steroid hormones in female sexual function and disfunction. Clin Obstet Gynecol. 2004; 3: 327-87.

2. Bitzer J. Contraception and sexuality. Ther. USC: 1994; 8: 32-7.

3. Davis A, Castano PM. Oral contraceptives and libido in women. Annu Rev Sex Res, 2004; 2: 133-47.

4. Witting K, Santila P, Jern P. Evaluation of the Female Sexual Function Index in a population based sample from Finland. Arch Sex Behav, 2008; 37: 912-24.

5. Wiegratz, Kutschera E, Lee J. Effect of four different oral contraceptives on various sex hormones and serum-binding globulins. Contraception. New York, Springer-Verlag. 2003

6. Graham CA, Bancroft J, Doll H. Greco T, Tanner A. Does oral contraceptive-induced reduction in free testosterone adversely affect the sexuality or mood of women? Psychoneuroendocrinology, 2007; 3: 437-9.
7. Greco T, Graham Ca, Bancroft J, Tanner A, Doll HA. The effects of oral contraceptives on androgen levels and their relevance to premenstrual mood and sexual interest: a comparison of two triphasic formulations containing norgestimate and either 35 or 25 microgram of ethinyl estradiol. Contraception. New York, Springer-Verlag. 2007

8. Panzer C, Wise S, Fantini. Impact of oral contraceptives on sex hormone-binding globulin and androgen level: retrospective study in women with sexual dysfunction. J Sex Med, 2006: 104-13.

9. Warnock J, Clayton A, Croft J, Segraves R, Boggs FC. Comparison of androgens in women with hypoactive sexual desire disorder: those on combined oral contraceptives COCs vs. those not on COCs. J Sex, 2006; 3: 878-82.

10. Walwiener M, Walwiener L, Seeger H, Mueck A, Zipfel S, Bitzer J, Walwiener C. Effect of Sex Hormones in oral contraceptives on the female sexual function score: a study in German female medical student. In Contraception (Ed.) New York, Springer-Verlag. 2010

11. Rosen R, Brown C, Heiman J, Leiblum, Meston C, Shabsigh R. The female sexual function index (FSFI): A multidimensional self-report instrument for the assessment of female sexual function. J Sex Marital Therapy, 2000; 26: 191-208. 